\title{
Characteristics of the Journal of UOEH
}

\author{
Kenzaburo TsuchiYa \\ President, University of Occupational and Environmental Health, Japan \\ Editor-in-chief, Editorial Board of the Journal of UOEH
}

The purpose of the University of Occupational and Environmental Health, Japan (UOEH), was described in the first issue, Volume One of the UOEH Journal published in March 1979, the second year after the establishment of the university. With regard to the nature of the journal, the editorial board of the journal and faculty members agreed that 1) the papers submitted not only by the staff belonging to the School of Medicine and the Schools of Nursing, Medical Technology and Occupational Health Nursing, UOEH, but those by educators as well as research workers from inside and outside Japan would also be accepted, 2) a high scientific level as a journal of health sciences be maintained, and that 3 ) although the journal would focus mainly on the occupational and environmental health sciences, articles in other fields of medicine would also be accepted.

Further, since the subjects of health care and occupational and environmental health are human beings, broader fields in terms of humanics should be included, e.g., bioethics, the philosophy on which the bio-medical sciences are based. Thus, the Journal of UOEH places emphasis on articles related to occupational and environmental health as well as on those covering the fields of basic medical science, clinical medicine, social medicine and other natural as well as cultural sciences, particularly, humanics. Ethics will become especially important in light of the recent rapid technological advances in the medical and health sciences.

Needless to say the Journal of UOEH is a journal for scientific papers and articles, and the papers accepted for publication will be decided according to a strict referee system. As mentioned, papers not only by the staff of UOEH but also those by educators and research workers inside as well as outside Japan are welcome. To cite an example, papers by members of the Society of Philosophy and Ethics in Medical Universities in Japan are expected to be submitted for publication in the near future. 


\author{
土 屋 健 三 郎 \\ 産業医科大学学長 産業医科大学雑誌編集委員長
}

産業医科大学は, 産業医科大学雑誌第一巻第一号（昭和 54 年 3 月）に述べたように, 産業医学およ び産業保健に指向された大学として設立されたものである。産業医科大学雑誌は大学設立一年後に第一 巻第一号が出版されたが，当時，編集委員会並びに教授会の合意として，（1）医学部並びに医療技術 短期大学 (専攻科地域看護学専攻を含む) 内の教員, 並びに研究者ばかりでなく, 他の, 国際社会を含 む教育, 研究者の論文を揭載すること（2）医学雑誌として高度な水準を保つことが約束された。し かし（3）医学は狭義での医学専門分野のみでなく, 自然科学並びに, 医療の対象が人間であるという 観点から, 広く総合人間学 (Humanics) 等の分野を含み得ることとした。即ち, 産業医科大学雑誌は, 産業医学並びに環境保健に関する論文に重点を置くが, その他の一般基礎医学, 臨床医学, 社会医学, また医学に関係する基礎科学，特に総合人間学に関係する論文をも収録し，医療の基本である心の問題 をも取り扱うこととした，特に最近の医学の進歩にともなって，その基本である倫理の問題は，医学の 一分野として議論する必要があると思われる，例えば，既にバイオエシックスや，その他医学に係わる 哲学の問題も取り上げている。 二十一世紀の医学, 特に産業医学や環境保健は新しい倫理基準を必要と することを,ここに改めて強調したい。

しかしながら, 産業医科大学雑誌はあくまでも学術論文のための雑誌であり, 㛜正なレフェリーによっ て掲載の採否が決められる。このような意味で, 本大学の教職員のみならず, 例えば産業医学や環境保 健を中心之する内外の論文, あるいは最近誕生した医学哲学倫理学会の会員などから質の高い, 多くの 論文が奇せられることを切に期待するものである. 